\title{
Trends in floods in West Africa: analysis based on 11 catchments in the region
}

\author{
B. N. Nka ${ }^{1,2}$, L. Oudin ${ }^{1}$, H. Karambiri ${ }^{2}$, J. E. Paturel ${ }^{3}$, and P. Ribstein ${ }^{1}$ \\ ${ }^{1}$ UMR 7619 METIS, Sorbonne Université, UPMC Université Paris 6, CNRS, EPHE, 4 Place Jussieu, 75005 Paris, France \\ ${ }^{2}$ International Institute for Water and Environmental Engineering (2iE), 01 BP 594 Ouagadougou 01, Burkina Faso \\ ${ }^{3}$ Institut de Recherche pour le Développement (IRD)/UMR HydroSciences Montpellier, 08 BP 3800 Abidjan 08, \\ Côte d'Ivoire
}

Correspondence to: B. N. Nka (bnnomo1@ hotmail.fr)

Received: 8 April 2015 - Published in Hydrol. Earth Syst. Sci. Discuss.: 29 May 2015

Revised: 28 October 2015 - Accepted: 2 November 2015 - Published: 27 November 2015

\begin{abstract}
After the drought of the 1970s in West Africa, the variability in rainfall and land use changes mostly affected flow, and recently flooding has been said to be an increasingly common occurrence throughout the whole of West Africa. These changes have raised many questions about the impact of climate change on the flood regimes in West African countries. This paper investigates whether floods are becoming more frequent or more severe and to what extent climate patterns have been responsible for these changes. We analyzed the trends in the floods occurring in 11 catchments within West Africa's main climate zones. The methodology includes two methods for sampling flood events, namely the AM (annual maximum) method and the POT (peak over threshold), and two perspectives of analysis are presented: long-term analysis based on two long flood time series and a regional perspective involving 11 catchments with shorter series. The Mann-Kendall trend test and the Pettitt break test were used to detect nonstationarities in the time series. The trends detected in flood time series were compared to the rainfall index trends and vegetation indices using contingency tables in order to identify the main driver of change in flood magnitude and flood frequency. The relation between the flood index and the physiographic index was evaluated through a success criterion and the Cramer criterion calculated from the contingency tables.

The results show the existence of trends in flood magnitude and flood frequency time series, with two main patterns. Sahelian floods show increasing flood trends and one Sudanian. catchment presents decreasing flood trends. For the overall catchments studied, trends in the maximum 5-day
\end{abstract}

consecutive rainfall index (R5d) show good coherence with trends in flood, while the trends in normalized difference vegetation indices (NDVIs) do not show a significant agreement with flood trends, meaning that this index has possibly no impact on the behavior of floods in the region.

\section{Introduction}

The drought that affected West African countries after the end of the 1960s is known as one of the "the most undisputed and largest recent climate changes recognized by the climate research community" (Dai and al., 2004) and is well documented in terms of rainfall variability (Le Barbé et al., 2002; Lebel et al., 2009; Paturel et al., 1998). Although there is recent agreement on the increase in rainfall since the end of the 1990s (Lebel et al., 2009; Lebel and Ali, 2009; L'Hôte et al., 2002), Mahé and Paturel (2009) showed that the mean rainfall of the decades from 1970 to 2009 remained lower than the decades from 1900 to 1970 . Moreover, some authors found an intensification of the rainfall regime in the Sahelian region since 2000 , characterized by a greater contribution of extreme precipitation to the annual total rainfall (Descroix et al., 2013; Panthou et al., 2014).

The rainfall deficit over West Africa has contrasting consequences on the hydrological regime of river basins. In Sudanian areas, the mean annual discharge of rivers has significantly and substantially decreased more than rainfall (Mahé, 2009; Mahé et al., 2013, 2011; Mahé and Olivry, 1995; Paturel et al., 2003), while in the Sahelian areas, a general in- 
crease in the runoff coefficient has been noted since the end of the 1980s, despite the low amount of precipitation compared to the 1950s (Albergel, 1987; Amani and Nguetora, 2002; Bricquet et al., 1996; Descroix et al., 2009; Mahé and Paturel, 2009; Roudier et al., 2014).

The causes of the runoff coefficient increase in Sahelian catchments is often considered to be the land clearing and land use changes that occurred in the region after 1970 (Amogu et al., 2010; Descroix et al., 2009; Mahe et al., 2010). Indeed, the largest variations in rainfall in the 1970s and 1980s over West Africa have consequently induced a reduction in vegetation cover, particularly in the Sahelian region (Anyamba and Tucker, 2005), and the growth of the population in Sahelian countries has led people to remove the natural vegetation in order to increase the surface area of cultivated land. However, evidence from recent data based on remotely sensed observations of vegetation have shown that the Sahelian region has been undergoing a "regreening" process since the beginning of the 1990s, due to the rainfall increase (Anyamba and Tucker, 2005; Fensholt et al., 2013; Herrmann et al., 2005).

Meanwhile, there is growing concern about fatalities related to floods in West Africa over the past half century (Di Baldassarre et al., 2010; Descroix et al., 2012; Sighomnou et al., 2013; Tschakert et al., 2010). Despite this widespread perception of increased flooding events in West Africa (Tarhule, 2005; Tschakert et al., 2010), there is very little information about the regional trend in floods and their potential causes, partly because of the scarcity and quality of long-term hydrological data. One can hypothesize that flood regimes have been impacted by the climatic and environmental changes that have occurred since 1970. Some authors have pointed out an increase in the amount of heavy daily rainfall that might have caused changes in flood regimes in areas where the infiltration capacity has been reduced (Descroix et al., 2013).

Identifying the drivers of change in the flood regimes of West Africa's catchments is a challenging task because of the heterogeneity of the region and the modification of hydrological functioning of drainage basins. However, the detection of trends in flood time series has scientific and economic importance. It is essential for planning protection systems against flooding, where the common assumption for system design is the stationarity of the flood regime (Kundzewicz et al., 2005). The main study is that of Di Baldassarre et al. (2010), which focused on flood trend analysis and concluded that for a majority of 30 river basins in Africa, there was no significant trend during the twentieth century. However, this study was based on a very large scale of catchments with quite diverse hydroclimatic settings and used sparse temporal data, which may have an effect on the coherence of the trends detected. This precludes a more in-depth analysis of the role of extreme rainfall variability and land use changes. The study of Aich et al. (2014) analyzed the link between maximum discharge (flood hazard) and flood damage on the Niger basin.
They concluded that there is a correlation between flood damage and maximum discharge evolution in the main climatic areas of the Niger basin during the period 1970-2010.

In the present study, we investigate the trends in flood magnitude and flood frequency of 11 catchments reflecting the main hydroclimatic conditions in West Africa. We also investigate the agreement between flood trends and climate and environmental indice trends in order to identify the potential drivers of flood variability. Because data from the catchments studied have different record lengths, we focus our analysis firstly on two long-term time series for an historical perspective of flood behavior and secondly on the 1970-2010 period, using the study's 11 catchments. Section 2 presents the general characteristics of the region and the data set used to create annual time series. In Sect. 3 we explain the methodology used for this analysis and Sect. 4 presents the results of this work.

\section{Study domain and original data}

The study domain refers to the region of West Africa. This region is usually divided into two climatic zones, the Sahelian and the Sudanian regions, separated by an isohyet of $750 \mathrm{~mm} \mathrm{yr}^{-1}$ (Fig. 1) as described by Descroix et al. (2009). As presented in Table 1, we collected the mean daily flow records of 11 catchments with areas ranging from 1750 to $12200 \mathrm{~km}^{2}$. These 11 catchments are considered representative of the hydroclimatic diversity of West Africa.

Following the abovementioned terminology, our database contains three Sahelian catchments - the Goudebo River at Falagontou, the Gorouol River at Koriziena, and the Dargol River at Kakassi - which are located north of isohyet $750 \mathrm{~mm}$. These catchments are on the right-bank tributaries of the Niger River. The other catchments located south of the isohyet $750 \mathrm{~mm}$ are Sudanian catchments. All these data have been subject to quality control before being included in the study. Time series of Burkina Faso were provided by the DGRE (Direction Générale des Ressources en Eau) in their rudimentary form, including gaps, and a particular care was taken in the selection of the target variable for this study. However, data for Senegal and Mali have been processed, and their time series have been examined critically by the research team of OMVS (Organsation pour la Mise en Valeur du fleuve Sénégal) and the IRD (Institut de Recherche pour le Développement) team of Senegal before being included in this study.

The hydrological functioning of West African rivers is closely related to rainfall seasonality, which is controlled by the West African monsoon system (Lebel and Ali, 2009). In both regions, the rainfall season is generally limited to the boreal summer months, i.e., from May to October. In the Sahelian region, rainfall length ranges from 2 to 4 months, with maximum rainfall occurring in August (Nicholson, 2013); this correspond to the flow season where flows are gener- 
Table 1. General information on the 11 catchments and the flow and rainfall data sets used for the study. Annual rainfall is computed over the 1960-1999 period. Values of missing years recorded for the catchments Fadougou, Sokoroto, Missira and Kedougou represent the amount of reconstructed maximum discharge for these catchments.

\begin{tabular}{|c|c|c|c|c|c|c|c|c|c|}
\hline Country & $\begin{array}{l}\text { Main } \\
\text { river }\end{array}$ & Tributary & $\begin{array}{l}\text { Gauging } \\
\text { station }\end{array}$ & $\begin{array}{c}\text { Area } \\
\left(\mathrm{km}^{2}\right)\end{array}$ & $\begin{array}{l}\text { First and } \\
\text { last years } \\
\text { for floods }\end{array}$ & $\begin{array}{c}\text { Missing } \\
\text { years }\end{array}$ & $\begin{array}{c}\text { Mean } \\
\text { annual } \\
\text { precipitation } \\
(\mathrm{mm})\end{array}$ & $\begin{array}{l}\text { Number } \\
\text { of rain } \\
\text { gauges } \\
\text { used }\end{array}$ & $\begin{array}{l}\text { First and } \\
\text { last years } \\
\text { for rainfall }\end{array}$ \\
\hline Burkina Faso & Niger & Goudebo & Falagontou & 3750 & 1987-2010 & 4 & 410 & 5 & 1970-2010 \\
\hline Burkina Faso & Niger & Gorouol & Koriziena & 2500 & 1970-2010 & 8 & 371 & 4 & 1970-2010 \\
\hline Niger & Niger & Dargol & Kakassi & 6950 & 1959-2009 & 12 & 408 & 6 & 1970-2010 \\
\hline Burkina Faso & Volta & Mouhoun & Samendeni & 4580 & 1970-2006 & 0 & 996 & 8 & 1970-2010 \\
\hline Burkina Faso & Volta & Noaho & Bittou & 4050 & 1973-2006 & 3 & 804 & 7 & 1970-2010 \\
\hline Burkina Faso & Volta & Bambassou & Batie & 5485 & 1971-2004 & 2 & 1006 & 6 & 1970-2010 \\
\hline Burkina Faso & Volta & Bougouribga & Diebougou & 12200 & 1970-2005 & 4 & 956 & 14 & 1970-2010 \\
\hline Mali & Senegal & Faleme & Fadougou & 9350 & 1950-2010 & 23 & 1073 & 7 & 1970-2000 \\
\hline Guinea & Senegal & Bafing & Sokoroto & 1750 & 1970-2010 & 12 & 1280 & 2 & 1970-2000 \\
\hline Senegal & Gambie & Koulountou & Missira & 6200 & 1970-2000 & 2 & 1375 & 4 & 1970-2000 \\
\hline Senegal & Gambie & Gambie & Kedougou & 8130 & 1970-2002 & 0 & 1262 & 7 & 1970-2000 \\
\hline
\end{tabular}

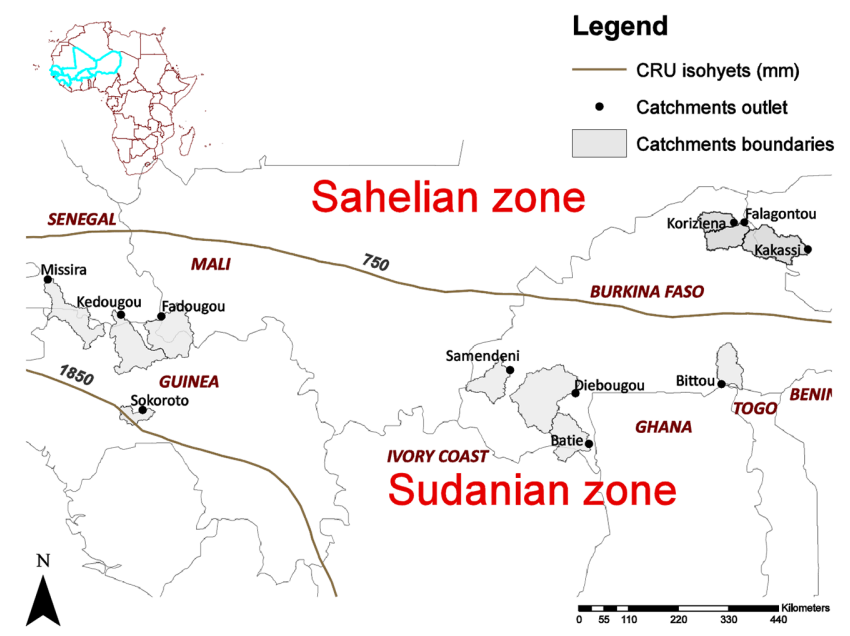

Figure 1. Location of the 11 West African catchments used for this study; the isohyets were created from climatic research unit (CRU) spatial rainfall data from 1960 to 1990.

alized spatially. The maximum discharge generally occurs within the month of August.

In the Sudanian region, flows generally span July to November. The precipitation that occurs from July to August causes the saturation of the ground from below. The maximum discharge occurs generally between the end of August and September, the rest of the year being too dry for small watersheds. Figure 2 presents the monthly hydrograph of two representative catchments of the West African rivers studied, the Dargol River at Kakassi in the Sahelian region and the Faleme River at Fadougou in the Sudanian region.

Ideally, the data set should have record periods spanning the same interval, but this is not the case for the 11 catchments studied. Only two long-term flow series were found,
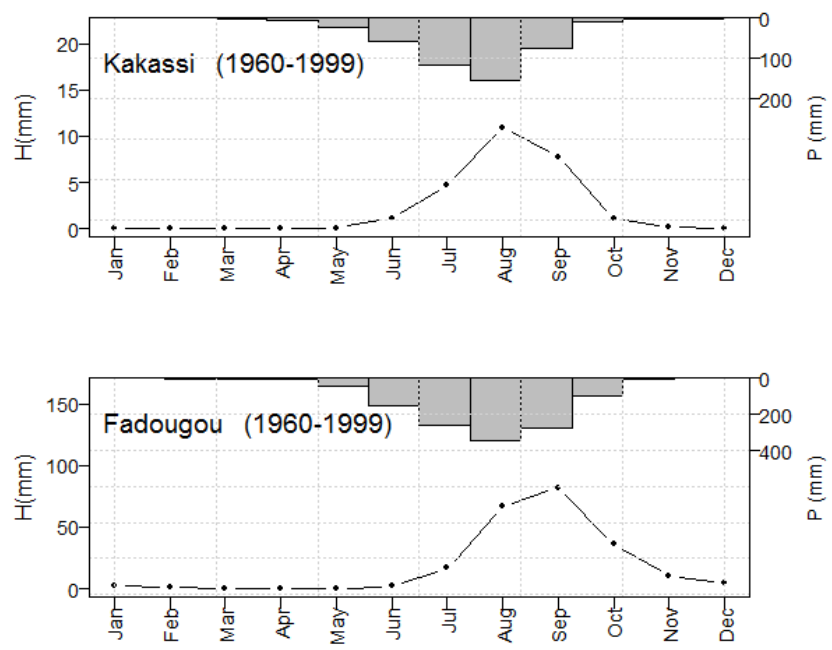

Figure 2. Mean monthly hydrograph for Kakassi (Sahelian catchment) and Fadougou (Sudanian catchment), 1960-1999.

the Dargol River at Kakassi (1959-2009) and the Faleme River at Fadougou (1950-2010). The nine other flow time series generally start after 1970 . Consequently, two data sets were considered in this study: a data set consisting of the long-term time series for the two catchments and a data set composed of more catchments (11) but over a shorter time period (typically from 1970 to 2010).

The latter data set with a shorter period of analysis ensures greater spatial coverage. It was considered for the 1970-2010 period, with at least 20 annual maximum records per catchment. This data set was used to assess the relation between the flood and rainfall indices. The former data set, with a longer period of analysis, increases the likelihood of identi- 
fying trends and provides an overview of the flood behavior before and after the drought that started in the 1970s.

Inherent uncertainties in using observations to detect trends in flood time series derive from the quality and quantity of data. Some problems linked to the quality of data, such as missing values and gaps in time series, can cause apparent changes and are complicating factors for the analysis of the data and interpretation of the results. However, the main difficulty in the area of study is the availability of long-term series with no gaps. In addition, compared to the Sahelian region, very few studies have investigated trends in flow in the Sudanian region. This is certainly due to a particular lack of data in this part of West Africa. In general, it is possible to find more catchments in the region, but the data of most of these catchments are often deficient, which makes it impossible to use them for the study of hydrological extremes. Thus, we decided to concentrate our analysis on the few catchments showing more reliable time series, and no supplementary treatment was carried out on these data. In addition, significant uncertainties of measurement can impact the results of trends, but there have been no significant changes in the measuring technique used for data in the West African region since 1970. Regarding the history of the gauging stations used in this study, there is no major hydraulic infrastructure within the catchments that can impact flows.

Daily rainfall data were obtained from the Système d'Informations Environnementales sur les Ressources en Eau et leur Modélisation (SIEREM) database (http://www. hydrosciences.fr/sierem/index_en.htm) for the 1970-2000 period. In Burkina Faso, we also collected data for the 20002010 period from the country's National Meteorological Service. For the data collected from other countries, data record periods ended in 2000 . Generally speaking, we were able to find a sufficient number of local rain gauges that allowed us to compute the mean areal rainfall of each catchment. The Thiessen polygon method was applied to determine the mean areal daily rainfall for each catchment. Table 1 presents the mean annual precipitation of the 11 catchments over the 1970-1999 period and the number of rain gauges used to obtain these values for each catchment.

The normalized difference vegetation index (NDVI; source: International Research Institute for Climate and Society Data library online) is used in this study as an environmental variable providing information on the evolution of vegetation or land degradation (Fensholt et al., 2013). NDVI data are derived from images obtained with the Advanced Very High Resolution Radiometer (AVHRR) instrument onboard the NOAA satellite series (Tucker et al., 2004). This is a product of the GIMMS (Global Inventory Modeling Mapping Studies), available for a 25-year period from 1981 to 2006. The NDVI values are recorded every 2 weeks on each $0.072^{\circ} \times 0.072^{\circ}$ pixel, allowing the study of seasonal and interannual vegetation changes. The NDVI data are dimensionless numbers varying from 0 to unity depending on vegetation density. NDVI values near 0 indicate very sparse vege- tation, while dense vegetation is indicated by NDVI values approaching unity.

\section{Methods}

The relatively large and homogeneous data set used in this study allows one to address the issue of flood nonstationarity in West Africa, with particular consideration given to the diverse results obtained according to rainfall and vegetation indices in the region. To this end, a series of methods were monitored to derive annual time series of high-flow characteristics, rainfall indices, and vegetation characteristics. For all these time series, we applied a trend detection test that is also presented in this section. Finally, the agreements between the trends detected for high flows and the trends detected for climatic and vegetation indices were compared.

\subsection{Flood sampling}

Two time series were derived from daily flow records using two sampling methods: annual maximum (AM) sampling and peak-over-threshold (POT) sampling.

Annual maximum sampling consists of extracting the peak values of daily discharge within the calendar year of a series. AM is a well-established and simple approach that allows the investigation of the changes in flood magnitude (Qmax) (Di Baldassarre et al., 2010; Robson et al., 1998). However, the disadvantage of this concept is that only the most important event is selected for years with more than one high flow, while in years without substantial flow, the event selected can correspond to a medium or even a low flow (Kundzewicz et al., 2005).

Figure 3 illustrates the specific Qmax (Qmax divided by the catchment area) for the 11 catchments studied. Figure 3 shows that all Qmax time series have skewed distributions. The Sokoroto River at Bafing is the smallest catchment in terms of area, but presents the highest specific maximum discharge values. Generally, Sahelian catchments have a lower specific Qmax than Sudanian catchments.

The second sample derived from daily flow series is the nPOT series. The nPOT time series presented in Fig. 4 were constructed from POT sampling, for which all independent floods exceeding a certain threshold are considered (Lang et al., 1999). The POT series are useful for investigating the trends in either flood frequency or flood magnitude (Svensson et al., 2005). In this study, we analyzed the flood frequency (nPOT), which is the number of floods extracted in each year of the time series the data were collected.

The strategy used for POT sampling is schematically represented in Fig. 4, and the following sequence was observed.

1. All nPOT must exceed the flow threshold $(u)$. In this study, the threshold was taken as the minimum value of the respective annual maximum time series. This choice was made because at least one nPOT per year can be 


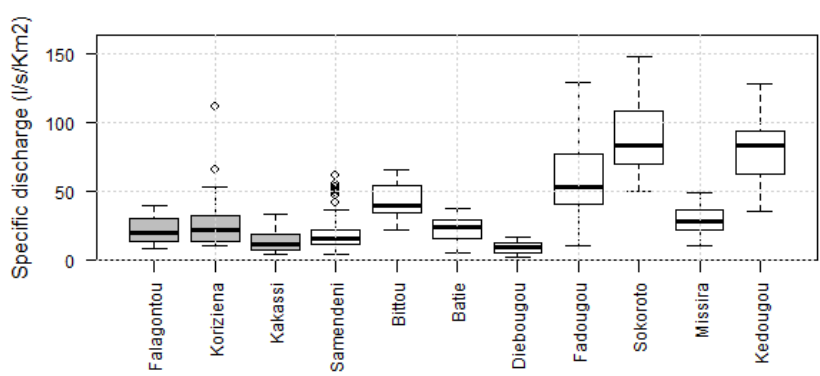

Figure 3. Boxplots of specific Qmax of each catchment within the period 1970-2010. The boxplot represents the median on the middle hinge and the 25th (75th) percentile on the lower (upper) hinge. The lower (upper) whisker is the border beyond which outliers are considered to be equal to $1.5 \times$ interquartile range -25 th $(+75$ th $)$. Empty circles represent outliers greater than the upper whisker or below the lower whisker. The three first boxes represent the time series for Sahelian catchments.

obtained for all the catchments studied while remaining within the range of maximum values sampled in the corresponding Qmax series.

2 The time between two consecutive nPOT $(\Theta)$ is greater than or equal to the average duration of half of the exceeding maximum discharges in the mean flood hydrograph. Consequently, a mean duration of flood events was estimated on the basis of historical flood events.

3 The minimum daily flow value $\left(X_{\min }\right)$ between two consecutive nPOT $X_{i}$ and $X_{i+1}$ shall be less than a second threshold that is $\mathrm{C} 1=0.5 \min \left(X_{i} ; X_{i+1}\right)$. Thus, we ensure that the two values sampled are derived from different and independent events.

Figure 5 provides a summary of the nPOT. It should be noted that with these criteria and given the hydrological behavior of some of these catchments, we did not obtain a large number of POT events per year for some catchments such as Samendeni, Sokoroto, and Missira.

\subsection{Rainfall and vegetation indices}

International research teams such as the Expert Team on Climate Change Detection Monitoring Indices (ETCCDMI) have proposed a set of climate indices enabling comparison across different regions (New et al., 2006; Peterson, 2002; Vincent et al., 2005). From this set of indices, we selected the most meaningful for the study of floods in the West African region.

For each catchment, we computed the annual time series of the rainfall indices presented in Table 2. These indices provide information on both intensity and frequency of rainfall characteristics that were subject to change within the last few decades in West Africa (Klein Tank et al., 2009; Ly et al., 2013; New et al., 2006; Sarr et al., 2013). Rtot and SDII provide information on the wetness of catchments within the

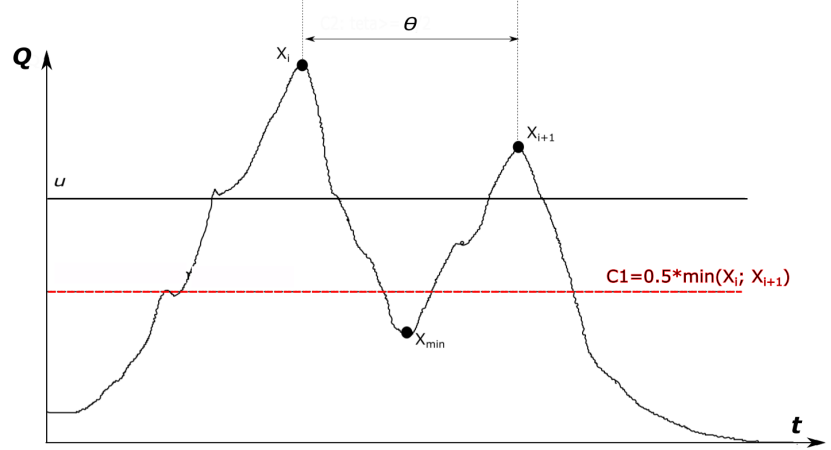

Figure 4. Extraction process of nPOT values. $u$ is the threshold above which all peak are selected; $\Theta$ is the time interval between two consecutive nPOT; $X_{\min }$ refers to the minimum daily discharge between two consecutive nPOT $X_{i}$ and $X_{i+1} ; \mathrm{C} 1$ is the minimum threshold between two consecutive nPOT.

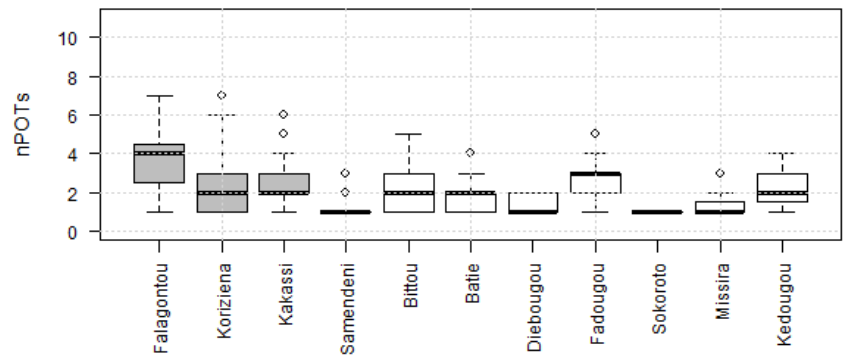

Figure 5. Boxplots for nPOT time series within the period 1970 2010 summarizing the characteristics of the nPOT series used. The boxplot represents the median on the middle hinge and the 25th (75th) percentile on the lower (upper) hinge. The lower (upper) whisker is the border beyond which outliers are considered to be equal to $1.5 \times$ interquartile range -25 th $(+75$ th). Empty circles represent outliers greater than the upper whisker or below the lower whisker. The three first boxes represent the time series for Sahelian catchments.

rainy season, while R20, Rmax, R95p, and R5d are valuable for the study of extreme rainfall patterns.

With reference to previous studies, the indices selected present observable trends since 1950 . The decrease in annual total rainfall in the 1950-2000 period over West Africa has been well documented (Le Barbé et al., 2002; Lebel and Ali, 2009; L'Hôte et al., 2002), but the climate has been less dry since the early 1990s (Nicholson, 2005; Ozer et al., 2002). As for the indices related to extreme climate, Descroix et al. (2013) and Panthou et al. (2013) noticed that extreme daily rainfall has increased over the central Sahel region. They also suggested that the contribution of extreme rainfall to the annual total rainfall has increased over the 2000s. Ly et al. (2013) came to the same conclusion for the 1961-1990 period in the Sahelian region. These trends are evaluated here in a comparative approach with flood trends.

For each catchment and each date, we computed the mean spatial value of all NDVI pixels within the catchment. The 
Table 2. Description of the rainfall indices used.

\begin{tabular}{lll}
\hline ID & Description & Unit \\
\hline Rtot & Annual total rainfall, where precipitation $\geq 1 \mathrm{~mm}$ & $\mathrm{~mm}$ \\
R20 & Annual number of days when precipitation $\geq 20 \mathrm{~mm}$ & days \\
Rmax & Daily maximum rainfall per year & $\mathrm{mm}$ \\
R95p & Sum of daily rainfall exceeding the 95th percentile & $\mathrm{mm}$ \\
R5d & Maximum rainfall over 5 consecutive days. & $\mathrm{mm}$ \\
SDII & Simple daily intensity index & $\mathrm{mm} \mathrm{day}^{-1}$ \\
& (annual total rainfall divided by & $\mathrm{mm} \mathrm{day}^{-1}$ \\
& the number of wet days in the year) & \\
\hline
\end{tabular}

seasonal evolution of NDVI is known to be closely related to the rainfall pattern, and since the catchments studied present similar hydrological regimes (one wet season and one dry season), we computed 3-yearly mean NDVI values for each catchment: the yearly means of the NDVI for the full 12 months (NDVI_m), for the dry season (NDVI_d) from January to June and for the wet season (NDVI_w) from July to December. This choice of dry and wet seasons was made to take into account the lag time of the greening process after the rainy season.

\subsection{Trends and breaks in the time series}

In this study, the Mann-Kendall (Kendall, 1975; Mann, 1945) and the Pettitt (Pettitt, 1979) tests are used to identify trends and break dates in the annual time series. These tests are recognized as being robust for trend analysis of hydroclimatic data in the sense that they are nonparametric and thus do not make assumptions on the distributions of the variables (Kundzewicz et al., 2005). For all these tests, the null hypothesis is that there is no trend or no break in the time series at the significance level 0.10 .

The result of the Mann-Kendall test is given by its two estimated coefficients, namely the correlation coefficient $\left(\tau_{\mathrm{MK}}\right)$ and the $p$ value $\left(\alpha_{\mathrm{MK}}\right)$. The $\tau_{\mathrm{MK}}$ value of the Mann-Kendall varies between -1 and 1 and is either positive or negative for increasing and decreasing trends, respectively. An absolute value close to 1 indicates that the correlation between the two variables involved (in this case the data and the time) is high. The value of $\alpha_{\mathrm{MK}}$ is then compared to the significance level of the test. The null hypothesis is rejected if $\alpha_{\mathrm{MK}}$ is less than the significance level; if not, the null hypothesis is not rejected.

The Pettitt test investigates the existence of a break in the time series. The result is given by a $p$ value $\left(\alpha_{\mathrm{PET}}\right)$ and the probable date for a break. As for the Mann-Kendall test, the Pettitt test $p$ value is compared to the significance level. If the $p$ value is less than the significance level, the null hypothesis is rejected. If not, the null hypothesis is not rejected and the computed date of change is rejected. This test was used only for the two long flood time series.

\subsection{Statistical agreement between flood evolution and rainfall-vegetation indices evolution}

For each catchment of the short series sample, we performed the Mann-Kendall test on the Qmax time series, the nPOT time series, and the physiographic indices (for either rainfall or vegetation); then the trend obtained on each flow index was compared to the trend in each physiographic index using contingency tables for all catchments. To obtain a synthetic assessment of the contingency tables, we computed two criteria.

The Cramer index (Cramer, 1946; Johnson, 2004) is commonly used to estimate the dependency between variables in contingency tables. Its value ranges between 0 and unity, a value of 1 meaning a complete dependency of the variables. The Cramer index is also associated with the $\chi$-squared test, which gives a $p$ value $(\alpha)$ indicating the significance of the test.

We also computed the success criterion (SC), inspired by the critical success index (Schaefer, 1990). The SC can be considered as a quality criterion, with values ranging from 0 to unity. However, the use of this criterion requires some assumptions about the known and possible combinations of trends between floods and rainfall. Table 3 presents the basic considerations made for the calculation of SC, and Eq. (1) gives the formulation of SC.

Success Criterion $=\mathrm{SC}=\frac{\sum \mathrm{CD}+\sum \mathrm{CR}}{\sum \mathrm{CD}+\sum \mathrm{FD}+\sum \mathrm{MD}+\sum \mathrm{CR}}$,

where $\mathrm{CD}$ (correct detection) is the number of catchments that present similar trends for both flood and physiographic indices, FD (false detection) is the number of catchments that present opposite trends for both flood and physiographic indices, MD (missed detection) is the number of catchments that are stationary for one index and nonstationary for the other, and CR (correct rejection) is the number of catchments that present nonstationary behavior for both indices.

The SC value gives the proportion of agreements (correct detection and correct rejection) between flood trends (either Qmax or nPOT) and each physiographic index trend in the whole catchment set. A value close to unity indicates good agreement between both flood and physiographic trends. By contrast, a value close to 0 indicates that there is no agreement between the trends in the indices involved.

\section{Results}

This section presents the results of the trend analyses on flood characteristics as well as on rainfall and vegetation indices. As mentioned in Sect. 2, the catchment set presents different record period lengths. We investigated the temporal variability in the trends in two catchments presenting long series. Then we investigated the spatial variability in the trends by analyzing the flood trends over the whole catchment set, but 
Table 3. Three-by-three contingency table of trends for flood and physiographic indices. Each cell contains the number of catchments respecting the trends in the row (for flood indices) and column (for physiographic indices).

\begin{tabular}{lccc}
\hline Flood index & \multicolumn{3}{c}{ Physiographic index } \\
\cline { 2 - 4 } & Positive & Negative & Stationary \\
\hline Positive & CD & FD & MD \\
Negative & FD & CD & MD \\
Stationarity & MD & MD & CR \\
\hline
\end{tabular}

CD: correct detection; FD: false detection; MD: missed detection; CR: correct rejection.

focusing on the 1970-2010 period. Flood trends were compared to rainfall trends, and, finally, flood trends were compared to vegetation trends over the 1981-2006 time period. This allowed us to identify the factor with the greatest influence on flooding.

\subsection{Historical perspectives of trends in flood magnitude and frequency}

For long-term analysis, we only considered the two long time series representing the climatic region of West Africa, namely the Dargol River at Kakassi and the Faleme River at Fadougou. The results of the Mann-Kendall and Pettitt tests performed on the flood time series of these two catchments are presented in Table 4.

The evolution of flood in the two long times series (Fig. 6) presents two main behavioral patterns. For the Dargol River at Kakassi, the Qmax and nPOT time series significantly increased over the 1959-2009 period according to the MannKendall test, and breaks were also detected with the Pettitt test. The break in the Qmax time series occurred in 1987 and for nPOT the break date occurred later, in 1993. The same tests were also applied to the subperiod time series for each flood index and the subseries were found to be stationary. The comparison of the mean Qmax and nPOT values within the two subperiods shows that the Qmax and nPOT values in the second subperiod were on average twice as high as their values in the first subperiod. For the Faleme River at Fadougou, the results highlight a decreasing Qmax trend with a break in 1971, while the nPOT time series was stationary. As for Kakassi, the Mann-Kendall and Pettitt tests performed on the subperiods of Fadougou's Qmax index revealed no significant trend and no significant break. According to the mean Qmax value in the subperiods, a decrease in Qmax at Fadougou between the two subperiods was also demonstrated.

The tests performed on the annual total rainfall index (Rtot) of the two catchments agreed on a break in the Rtot in 1967, which corresponds to the beginning of the drought. The mean value decreased from the first subperiod to the second. For Kakassi, no significant trend was detected in the
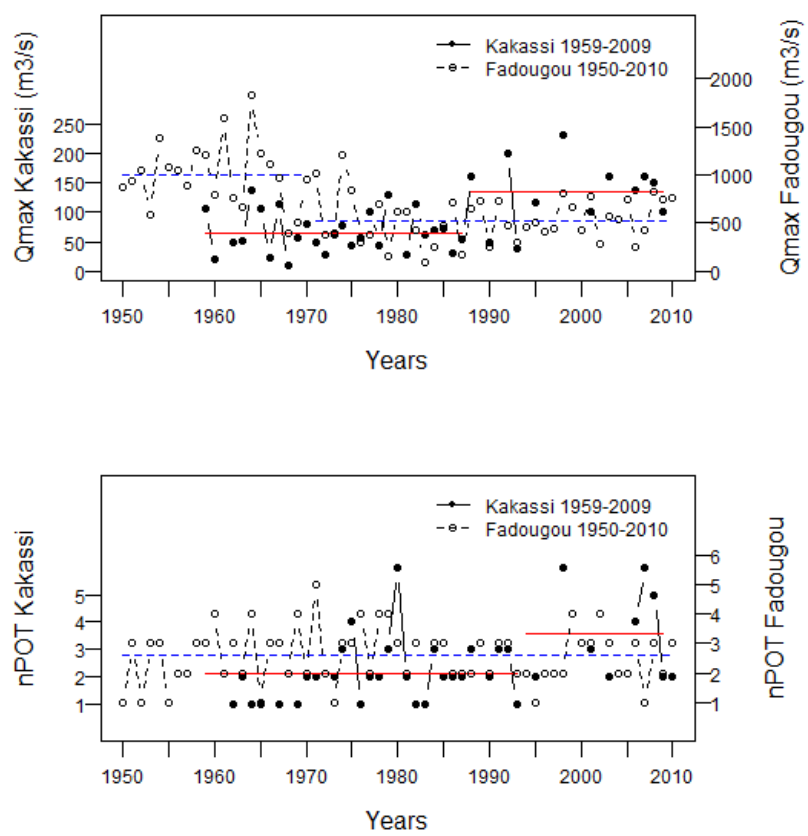

Figure 6. Qmax and nPOT of long-term time series and segmentation according to the Pettitt break test. The dashed blue lines (solid red lines) represent the mean value of the flood index for each subperiod at Fadougou (Kakassi).

rainfall index time series, but a break date occurred for the simple daily intensity index (SDII) in 1993. In this case, the mean SDII value was higher in the second subperiod, meaning that daily rainfall over the catchment was less frequent but more intense, which was also observed in previous studies (Descroix et al., 2013; Le Barbé et al., 2002; Panthou et al., 2014). As for Fadougou, all rainfall indices presented significant negative trends, and break dates all occurred within the 1967-1977 period, i.e., within the drought period.

Considering the Dargol River at Kakassi, we can assume that after the drought, the catchment experienced a stationary flood regime between the end of 1960 and the beginning of 1990. Since the end of the 1980s, substantial changes in the catchment led to an increase in flood magnitude and flood frequency. In the Sahelian zone, land use changes and land clearing were often mentioned as the main contributing factors of runoff increase since 1987. The coherence of a break in the SDII time series with the Qmax and nPOT time series for this catchment suggests that flooding in these Sahelian catchments has been rising by more than what can be explained by land use changes alone and that some rainfall indices could have an impact on the increase in flooding. Interestingly, the $p$ values of the Pettitt test for other rainfall indices such as the R20 (0.13) and R5d (0.13) are close to the significance level (0.10). Although these $p$ values are not significant, the estimated break dates for these indices' time series (1993 for R20 and 1987 for R5d) are in the same period as the Qmax and nPOT breaks, which suggests agree- 
Table 4. Results of Mann-Kendall and Pettitt tests on Kakassi and Fadougou time series (flood and rainfall indices): “+”" for significant positive trend; “-” for significant negative trend; "0” for no significant trend.

\begin{tabular}{|c|c|c|c|c|c|c|c|c|}
\hline & & \multicolumn{3}{|c|}{ Mann-Kendall } & \multicolumn{2}{|c|}{ Pettitt } & \multicolumn{2}{|c|}{ Conclusions } \\
\hline & & $\alpha_{\mathrm{MK}}$ & $\tau_{\mathrm{MK}}$ & Conclusion & $\alpha_{\text {PET }}$ & Break date & Subperiod & Mean by subperiod \\
\hline \multirow{8}{*}{ 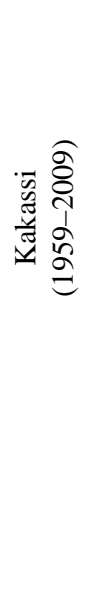 } & $\operatorname{Qmax}\left(\mathrm{m}^{3} \mathrm{~s}^{-1}\right)$ & 0.01 & 0.3 & + & 0.01 & 1987 & $\begin{array}{l}1959-1987 \\
1988-2009\end{array}$ & $\begin{array}{c}65 \\
135 \\
\end{array}$ \\
\hline & nPOT (-) & 0 & 0.48 & + & 0.05 & 1993 & $\begin{array}{l}1959-1993 \\
1994-2009\end{array}$ & $\begin{array}{l}2 \\
4\end{array}$ \\
\hline & Rtot (mm) & 0.12 & -0.17 & 0 & 0.06 & 1967 & $\begin{array}{l}1959-1967 \\
1968-2009\end{array}$ & $\begin{array}{l}523 \\
398 \\
\end{array}$ \\
\hline & R20 (-) & 0.49 & 0.08 & 0 & 0.13 & No break & - & - \\
\hline & $\mathrm{Rmax}(\mathrm{mm})$ & 0.35 & 0.11 & 0 & 0.22 & No break & - & - \\
\hline & R95 (mm) & 0.78 & 0.03 & 0 & 0.27 & No break & - & - \\
\hline & $\mathrm{R} 5 \mathrm{~d}(\mathrm{~mm})$ & 0.23 & 0.14 & 0 & 0.13 & No break & - & - \\
\hline & SDII (mm) & 0.48 & 0.08 & 0 & 0.08 & 1993 & $\begin{array}{l}1959-1993 \\
1994-2009\end{array}$ & $\begin{array}{l}7.4 \\
8.9\end{array}$ \\
\hline \multirow{8}{*}{ 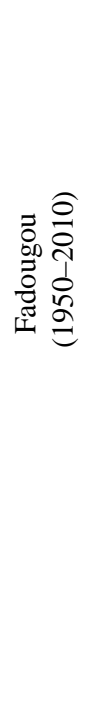 } & Qmax* $\left(\mathrm{m}^{3} \mathrm{~s}^{-1}\right)$ & 0 & -0.38 & - & 0 & 1971 & $\begin{array}{l}1950-1971 \\
1972-2010\end{array}$ & $\begin{array}{c}1006 \\
525\end{array}$ \\
\hline & nPOT $^{*}(-)$ & 0.96 & 0.01 & 0 & 0.51 & No break & - & - \\
\hline & Rtot (mm) & 0 & -0.47 & - & 0 & 1967 & $\begin{array}{l}1950-1967 \\
1968-2000 \\
\end{array}$ & $\begin{array}{l}1571 \\
1070 \\
\end{array}$ \\
\hline & R20 (-) & 0 & -0.47 & - & 0 & 1976 & $\begin{array}{l}1950-1976 \\
1977-2000\end{array}$ & $\begin{array}{l}25 \\
16 \\
\end{array}$ \\
\hline & $\operatorname{Rmax}(\mathrm{mm})$ & 0 & 0.28 & 0 & 0.01 & 1966 & $\begin{array}{l}1950-1966 \\
1966-2000\end{array}$ & $\begin{array}{c}95.6 \\
62\end{array}$ \\
\hline & $\mathrm{R} 95 \mathrm{p}$ (mm) & 0 & -0.44 & - & 0 & 1967 & $\begin{array}{l}1950-1967 \\
1968-2000\end{array}$ & $\begin{array}{l}440 \\
180\end{array}$ \\
\hline & $\mathrm{R} 5 \mathrm{~d}(\mathrm{~mm})$ & 0 & -0.32 & - & 0 & 1967 & $\begin{array}{l}1950-1967 \\
1968-2000\end{array}$ & $\begin{array}{l}184 \\
126 \\
\end{array}$ \\
\hline & SDII (mm) & 0 & -0.52 & - & 0 & 1977 & $\begin{array}{l}1950-1977 \\
1978-2000\end{array}$ & $\begin{array}{l}15.3 \\
11.1\end{array}$ \\
\hline
\end{tabular}

* For Fadougou, the Qmax and nPOT tests were performed on two periods: first for the 1950-2010 period and then for the 1950-2000 period for the comparison with rainfall index time series with a shorter length. The results obtained were the same for the two periods and for Qmax and nPOT.

ment with the breaks in flood time series. Finally, these results show that for the Faleme River at Fadougou, the Qmax decrease within the 1950-2000 period is consistent with the decrease in rainfall indices over the 1950-2000 period. Even if the 1950-2010 period is considered, the Fadougou Qmax still shows a decreasing trend, but unfortunately the rainfall time series for this catchment stopped in the year 2000 , so no information was provided for the last decade. The decrease in Qmax for Faleme at Fadougou, which is in agreement with the decrease in the annual discharge of the Sudanian rivers, reinforces the hypothesis that strongly decreasing groundwater flow is the factor explaining the high reduction in discharges with regard to the rainfall reduction since the 1970s in the Sudanian basins.

\subsection{Regional perspective of trends in flood magnitude and frequency}

To assess the flood trends from a regional perspective, we focused on short time series since 1970. The results of the Mann-Kendall trend test applied to Qmax and nPOT of the 11 catchments studied are presented in Table 5. Eight out of the 11 catchments do not show significant trends in Qmax, while the remaining three catchments present increasing trends (the Dargol River at Kakassi, the Gorouol River at Koriziena, and the Goudebo River at Falagontou).

When using the short time series, the trend detected in the Qmax time series of the Falémé River at Fadougou in Sect. 4.1 is no longer dominant. This suggests that since 
Table 5. Results of Mann-Kendall trend test on Qmax and nPOT time series for the 11 shorter time series: "+" for significant positive trend; "_"for significant negative trend; "0" for no significant trend.

\begin{tabular}{|c|c|c|c|c|c|c|c|c|}
\hline \multirow[t]{2}{*}{ Catchments } & \multirow[t]{2}{*}{ Area $\left(\mathrm{km}^{2}\right)$} & \multirow[t]{2}{*}{ Period } & \multicolumn{2}{|c|}{ Mann-Kendall Qmax } & \multirow[t]{2}{*}{ Conclusion } & \multicolumn{2}{|c|}{ Mann-Kendall nPOT } & \multirow[t]{2}{*}{ Conclusion } \\
\hline & & & $\alpha_{\mathrm{MK}}$ & $\tau_{\mathrm{MK}}$ & & $\alpha_{\mathrm{MK}}$ & $\tau_{\mathrm{MK}}$ & \\
\hline Falagontou & 3750 & $1987-2010$ & 0 & 0.46 & + & 0.04 & 0.36 & + \\
\hline Koriziena & 2500 & 1970-2010 & 0.03 & 0.27 & + & 0.07 & 0.25 & + \\
\hline Kakassi & 6950 & $1970-2010$ & 0.01 & 0.35 & + & 0.07 & 0.25 & + \\
\hline Samendeni & 4580 & 1970-2006 & 0.34 & 0.11 & 0 & 0.77 & 0.05 & 0 \\
\hline Bittou & 4050 & $1973-2006$ & 0.66 & 0.07 & 0 & 0.99 & 0 & 0 \\
\hline Batie & 5485 & 1971-2004 & 0.28 & 0.14 & 0 & 1 & 0 & 0 \\
\hline Diebougou & 12200 & $1970-2005$ & 0.45 & 0.1 & 0 & 0.19 & 0.19 & 0 \\
\hline Fadougou & 9350 & $1970-2010$ & 0.78 & -0.04 & 0 & 0.52 & -0.08 & 0 \\
\hline Sokoroto & 1750 & 1970-2010 & 0.67 & -0.06 & 0 & 0.83 & -0.03 & 0 \\
\hline Missira & 6200 & $1970-2000$ & 1 & 0 & 0 & 0.87 & -0.03 & 0 \\
\hline Kedougou & 8130 & 1970-2002 & 0.8 & 0.03 & 0 & 0.49 & -0.1 & 0 \\
\hline
\end{tabular}

the 1970 drought, the catchment has experienced stationary behavior with regard to its flood regime, while the Kakassi Qmax and nPOT time series still exhibit an increasing trend since 1970.

The results of the Mann-Kendall trend test on nPOT are similar to the flood magnitude results. The three Sahelian catchments also present a significant positive trend, all the remaining time series being stationary. These results suggest that the Sahelian catchments analyzed in this study have experienced more frequent floods.

The few significant trends detected in this section contrast with the perception that floods had regionally increased in West Africa, but these results are consistent with the results obtained by Di Baldassarre et al. (2010), who found $17 \%$ significant trends detected in a global database of 79 annual maximum time series in Africa before the 2000s.

However, it is important to note the clustering of the trends detected. All positive trends were detected for the three Sahelian catchments. This is in line with the "Sahelian paradox" (Descroix et al., 2009), which implies an increase in annual runoff coefficients while at the same time annual rainfall remains low compared to wet years (1950-1970).

To identify the similarities between flood patterns and environmental indices more accurately, the agreement between flood trends and physiographic index trends for the catchments studied are analyzed hereafter, first over the entire set of catchments with particular attention paid to the same time interval for the flood and physiographic index time series.

When analyzing all catchments at the same time, we expect the rainfall-runoff relationships of the 11 catchments studied to be quite different, since the catchments are known to have different hydrological processes due to the spatial variability in the climate and the heterogeneity of the soil. However, this has been considered an advantage in this section because it more clearly identifies which index is in agreement with the flood trends in the two climatic zones.
Table 6. SC and Cramer criterion values for precipitation index trends compared to Qmax trends and nPOT trends in the set of 11 short-term catchments.

\begin{tabular}{lcccccccc}
\hline & \multicolumn{3}{c}{ Qmax time series } & & \multicolumn{3}{c}{ nPOT time series } \\
\cline { 2 - 3 } \cline { 7 - 9 } & SC & $\alpha$ & Cramer & & SC & $\alpha$ & Cramer \\
\hline Rtot & 0.82 & 0.59 & 0.16 & & 0.82 & 0.59 & 0.16 \\
R20 & 0.36 & 0.63 & 0.29 & & 0.36 & 0.63 & 0.29 \\
Rmax & 0.55 & 1 & 0 & & 0.55 & 1 & 0 \\
R95p & 0.55 & 1 & 0 & & 0.55 & 1 & 0 \\
R5d & 0.73 & 0.24 & 0.35 & & 0.73 & 0.24 & 0.35 \\
SDII & 0.36 & 0.63 & 0.29 & & 0.36 & 0.63 & 0.29 \\
\hline
\end{tabular}

The results presented in Table 6 on the SC and Cramer criteria show similar Qmax and nPOT scores. The best SC scores are recorded for Rtot (0.82) and R5d (0.73) in both cases. The other indices showed an SC score between 0.36 and 0.55 , which will be considered as nonsignificant given the small number of catchments. The Cramer criterion has low scores for the Rtot (0.16) and R5d (0.35) indices in both cases, with associated $p$ values $(\alpha)$ higher than 0.10 , meaning that these scores are not significant and conclusions cannot be drawn on the relation between flood trends and rainfall index trends. However, these results show good consistency between the two criteria chosen for this analysis and highlight two main indices (Rtot and R5d) for which trends are in agreement with flood trends (Qmax and nPOT) according to the SC.

As mentioned above, we used series of different lengths, which may have had an effect on the coherence of the trends detected. Abdul Aziz and Burn (2006), Hamed (2008), and Burn et al. (2004) showed that using the Mann-Kendall trend test on different sections of the same time series can lead to contradicting results, due to the existence of non-monotonic temporal patterns in time series. This is also true for the 
Table 7. SC and Cramer criterion values for precipitation index trends compared to Qmax trends and nPOT trends for the seven homogeneous catchments of Burkina Faso.

\begin{tabular}{lcccccccc}
\hline & \multicolumn{3}{c}{ Qmax time series } & & \multicolumn{3}{c}{ nPOT time series } \\
\cline { 2 - 3 } \cline { 7 - 9 } & SC & $\alpha$ & Cramer & & SC & $\alpha$ & Cramer \\
\hline Rtot & 0.71 & 0.88 & 0.06 & & 0.71 & 0.88 & 0.06 \\
R20 & 0.57 & 1 & 0 & & 0.57 & 1 & 0 \\
Rmax & 0.71 & 0.88 & 0.06 & & 0.71 & 0.88 & 0.06 \\
R95p & 0.71 & 0.74 & 0.13 & & 0.71 & 0.74 & 0.13 \\
R5d & 1 & 0.06 & 0.71 & & 1 & 0.06 & 0.71 \\
SDII & 0.57 & 1 & 0 & & 0.57 & 1 & 0 \\
\hline
\end{tabular}

Fadougou time series as presented above. Therefore, for better coherence of the period in the analysis, only the Burkina Faso catchments will be used in the following, since they present longer time series; this allows us to analyze trends in the 1970-2010 period. The Goudebo River at Falagontou, the Gourouol at Koriziena, and the Dargol at Kakassi are considered hereafter for Sahelian catchments, and the Mouhoun River at Samendeni, the Noaho at Bittou, the Bambassou at Batie and the Bougouriba at Diebougou are considered for Sudanian catchments. The new SC and Cramer test values are presented in Table 7.

According to the results obtained when catchments with more homogeneous time series periods are considered, the R5d index appears to match the flood trends in the two climatic areas perfectly. For this index, the $\mathrm{SC}$ is equal to 1 , and the Cramer criterion is significant, with a high score of 0.71 for Qmax and nPOT. This suggests that the R5d index is the overriding climatic factor that is most likely to impact the flood behavior in the two climatic zones. This could be attributed to the fact that for the range of catchment areas studied herein, the maximum discharge was found with a substantial accumulation of rainfall recorded over several days.

To take into account the difference between the climatic zones, the trends in the seven catchments in Burkina Faso were calculated in a more detailed analysis to determine which rainfall indices match flooding trends for each climatic zone. In this case, the Cramer criterion was not calculated since the number of catchments taken into account for each group was too low.

According to the results presented in Table 8, the Sahelian flood trends are the same for three indices, namely R20, $\mathrm{R} 5 \mathrm{~d}$, and SDII. In this case, they all presented a significant increase, thus confirming the results obtained so far on the long time series of the Dargol River at Kakassi. In this respect, Descroix et al. (2013) showed that in the central Sahel, the mean daily rainfall has increased in 2000-2010 compared to 1971-1990, and its value reached the value of wet decades (1950-1970). The number of heavy rainfall days (R20) also increased over the 1990-2010 decades in the central Sahel. The greatest contribution of extreme rainy days in the an-
Table 8. SC and Cramer criterion values for precipitation index trends compared to Qmax trends and nPOT trends for the seven homogeneous catchments in Burkina Faso, three Sahelian catchments, and four Sudanian catchments.

\begin{tabular}{lll}
\hline $\begin{array}{l}\text { Rainfall } \\
\text { indices }\end{array}$ & $\begin{array}{l}\text { SC for Sahelian } \\
\text { catchments }\end{array}$ & $\begin{array}{l}\text { SC for Sudanian } \\
\text { catchments }\end{array}$ \\
\hline Rtot & 0.33 & 1 \\
R20 & 1 & 0.25 \\
Rmax & 0.33 & 1 \\
R95p & 0.67 & 0.75 \\
R5d & 1 & 1 \\
SDII & 1 & 0.25 \\
\hline
\end{tabular}

nual total rainfall since the beginning of 1990s (Descroix et al., 2013; Panthou et al., 2014) can also explain the increasing SDII trend since 1970 for the Sahelian catchments presented here.

For the Sudanian catchments, the Rtot, Rmax, and R5d indices showed the same trend as the Qmax and nPOT for the group's four catchments, as has already been shown in the long-term perspective analysis of Fadougou.

\subsection{Agreements between flood trends and NDVI trends}

Generally speaking, NDVI characteristics tend to increase for the studied catchments over the 1981-2006 period, and this was more pronounced for NDVI_w and the Sahelian catchments. According to the results of the Mann-Kendall trend test presented in Table 9, similar behavior for NDVI_w and NDVI_m was detected in 9 of the 11 catchments investigated. When integrating NDVI_d, only five catchments showed similar trends for the three vegetation indices.

Concerning the results of SC regarding the flood-NDVI indices presented in Table 10, the agreements are similar between Qmax and NDVI on the one hand and between nPOT and NDVI on the other hand. The Cramer index, presents very poor scores indicating that the relation between the flood index trends and the NDVI trends is not significant.

With regard to the NDVI, several publications have established that the Sahelian region has been going through a "regreening" process for almost 20 years now (Anyamba and Tucker, 2005; Fensholt et al., 2013; Herrmann et al., 2005). The NDVI changes on the catchments used in this study confirm this theory. However, this points out an obvious discrepancy with the "Sahelian paradox" concept, which implies an increase in the runoff coefficient due to land clearing. In that respect, Dardel et al. (2014) explained that these two behavioral patterns of the vegetation index can occur in the same area but on different spatial scales depending on the type of soil. 
Table 9. NDVI time series trends for the 11 catchments studied over the period 1981-2006 according to the Mann-Kendall tests: "+", significant positive trend; "0", no significant trend.

\begin{tabular}{lccc}
\hline & NDVI_m & NDVI_w & NDVI_d \\
\hline Falagontou & 0 & + & 0 \\
Kakassi & + & + & 0 \\
Koriziena & + & + & 0 \\
Samendeni & + & + & + \\
Bittou & + & + & + \\
Batie & + & + & + \\
Diebougou & + & + & 0 \\
Fadougou & + & + & 0 \\
Sokoroto & 0 & 0 & 0 \\
Missira & + & 0 & + \\
Kedougou & 0 & 0 & 0 \\
\hline
\end{tabular}

Table 10. SC and Cramer criterion values for the NDVI trends compared to Qmax trends and nPOT trends for the set of 11 catchments.

\begin{tabular}{lcccccccc}
\hline & \multicolumn{3}{c}{ Qmax time series } & & \multicolumn{3}{c}{ nPOT time series } \\
\cline { 2 - 3 } \cline { 7 - 9 } & SC & $\alpha$ & Cramer & & SC & $\alpha$ & Cramer \\
\hline NDVI_m & 0.36 & 0.69 & 0.12 & & 0.45 & 1 & 0 \\
NDVI_d & 0.55 & 1 & 0 & & 0.55 & 0.63 & 0.15 \\
NDVI_w & 0.55 & 1 & 0 & & 0.45 & 0.63 & 0.15 \\
\hline
\end{tabular}

\section{Conclusion}

This paper aimed to study the trends in maximum flows in West African rivers, and the study was based on 11 catchments of Sahelian and Sudanian zones of the region. To isolate the related climate and environmental impact on flood regime, we compared the trends in floods with the trends in physiographic variables of the medium-size catchments $\left(1750-12200 \mathrm{~km}^{2}\right)$. However, this study was based on a small sample of catchments considering the size of the region; the methodology applied allows us to confidently assert that for the set of data used two opposite trends can be observed regarding flood magnitude and flood frequency depending on the climatic zone.

The Sahelian catchments studied showed increasing trends in both flood magnitude and flood frequency, in accordance with the evolution of flow in Sahelian catchments attributed to the increase in annual runoff coefficients, but we also found significant similarities between flood trends and the trends indicated by certain extreme rainfall indices, namely the amount of heavy rainfall, the maximum amount of rainfall in 5 consecutive days, and the mean daily rainfall. This climate signal is possibly another aggravating factor of the increase in runoff coefficients in the Sahelian region. Since the number of catchments was relatively low, this result needs to be confirmed with other catchments.
For the Sudanian catchments studied, we identified only one decreasing trend in flood magnitude in the long time series, but the large sample of short time series used can be considered stationary with respect to flood magnitude and occurrence. The decreasing trends, as well as the stationarity of flood time series, are more likely attributable to the evolution in mean rainfall since 1970, which has induced a continual decrease in base flow (Mahé, 2009; Mahé et al., 2011).

We did not find a significant link between NDVI trends and flood magnitude trends. Therefore, the overall increase in NDVI does not appear here as a particular environmental pattern affecting flood magnitude trends, but rather as a regional behavior related to the resurgence of rainfall.

For years now, the design of hydraulics structures has been based on standards computed since 1960, with the hypothesis that extreme hydrological regimes are stationary, but after the drought in the 1970s, a number of elements contributed to the alteration of the hydrological regime in West Africa, such as demographic changes, increasing urbanization, and land usage, to mention a few known examples. The change in watershed environment and the results presented in this study suggest that the assumption of stationarity of floods is no longer valid for some catchments, and special care has to be taken when designing hydraulic structures, specifically with the use of old standards for the calculation of design flood.

Limitations inherent to the rainfall-runoff relationship analysis using statistical tools derive from the fact that hydrological processes as well as their spatial and temporal variability are not taken into account. It is therefore important to use hydrological models, which have the advantage of more accurately accounting for certain hydrological processes.

Acknowledgements. We are very grateful to all reviewers of this article for their relevant comments and the teams of IRD of Senegal and DGRE of Burkina Faso for providing us with data used in this study.

Edited by: F. Pappenberger

\section{References}

Abdul Aziz, O. I. and Burn, D. H.: Trends and variability in the hydrological regime of the Mackenzie River Basin, J. Hydrol., 319, 282-294, doi:10.1016/j.jhydrol.2005.06.039, 2006.

Aich, V., Koné, B., Hattermann, F. F., and Müller, E. N.: Floods in the Niger basin - analysis and attribution, Nat. Hazards Earth Syst. Sci. Discuss., 2, 5171-5212, doi:10.5194/nhessd-2-51712014, 2014.

Albergel, J.: Sécheresse, désertification et ressources en eau de surface - Application aux petits bassins du Burkina Faso, in: The Influence of Climate Change and Climatic Variability on the Hydrologic Regime and Water Resources, Proceedings of the Vancouver Symposium, Vancouver, Canada, August 1987, IAHS Publi. no. 168, 355-365, 1987. 
Amani, A. and Nguetora, M.: Evidence d'une modification du regime hydrologique du fleuve Niger a Niamey, in: FRIEND 2002 - Regional Hydrology: Briging the Gap between Research and Practice, Porceedings of the fourth International FRIEND Conference held at Cape Town, South Africa, March 2002, IAHS Publ. no. 274, 449-457, 2002.

Amogu, O., Descroix, L., Yéro, K. S., Le Breton, E., Mamadou, I., Ali, A., Vischel, T., Bader, J.-C., Moussa, I. B., Gautier, E., Boubkraoui, S., and Belleudy, P.: Increasing river flows in the Sahel?, Water, 2, 170-199, doi:10.3390/w2020170, 2010.

Anyamba, A. and Tucker, C. J.: Analysis of Sahelian vegetation dynamics using NOAA-AVHRR NDVI data from 1981-2003, J. Arid Environ., 63, 596-614, 2005.

Bricquet, J. P., Mahé, G., Bamba, F., and Olivry, J.-C.: Changements climatiques récents et modification du régime hydrologique du fleuve Niger Koulikoro (Mali), IAHS Publ. 238, 157-166, 1996.

Burn, D. H., Cunderlik, J. M., and Pietroniro, A.: Hydrological trends and variability in the Liard River basin/Tendances hydrologiques et variabilité dans le basin de la rivière Liard, Hydrolog. Sci. J., 49, 53-67, doi:10.1623/hysj.49.1.53.53994, 2004.

Cramer, H.: Mathematical Methods of Statistics, Princeton University Press, Princeton, USA, 1946.

Dai, A., Lamb, P. J., Trenberth, K. E., Hulme, M., Jones, P. D., and Xie, P.: The recent Sahel drought is real, Int. J. Climatol., 24, 1323-1331, doi:10.1002/joc.1083, 2004.

Dardel, C., Kergoat, L., Hiernaux, P., Grippa, M., Mougin, E., Ciais, P., and Nguyen, C.-C.: Rain-use-efficiency: what it tells us about the conflicting Sahel greening and Sahelian paradox, Remote Sens., 6, 3446-3474, doi:10.3390/rs6043446, 2014.

Descroix, L., Mahé, G., Lebel, T., Favreau, G., Galle, S., Gautier, E., Olivry, J.-C., Albergel, J., Amogu, O., Cappelaere, B., Dessouassi, R., Diedhiou, A., Le Breton, E., Mamadou, I., and Sighomnou, D.: Spatio-temporal variability of hydrological regimes around the boundaries between Sahelian and Sudanian areas of West Africa: a synthesis, J. Hydrol., 375, 90-102, doi:10.1016/j.jhydrol.2008.12.012, 2009.

Descroix, L., Genthon, P., Amogu, O., Rajot, J.-L., Sighomnou, D., and Vauclin, M.: Change in Sahelian Rivers hydrograph: The case of recent red floods of the Niger River in the Niamey region, Global Planet. Change, 98-99, 18-30, doi:10.1016/j.gloplacha.2012.07.009, 2012.

Descroix, L., Niang, D., Dacosta, H., Panthou, G., Quantin, G., and Diedhou, A.: Évolution des pluies de cumul élevé et recrudescence des crues depuis 1951 dans le bassin du Niger moyen (Sahel), Climatologie, 10, 37-49, 2013.

Di Baldassarre, G., Montanari, A., Lins, H., Koutsoyiannis, D., Brandimarte, L., and Blöschl, G.: Flood fatalities in Africa: From diagnosis to mitigation, Geophys. Res. Lett., 37, L22402, doi:10.1029/2010GL045467, 2010.

Fensholt, R., Rasmussen, K., Kaspersen, P., Huber, S., Horion, S., and Swinnen, E.: Assessing land degradation/recovery in the African Sahel from long-term Earth observation based primary productivity and precipitation relationships, Remote Sens., 5, 664-686, doi:10.3390/rs5020664, 2013.

Hamed, K. H.: Trend detection in hydrologic data: the MannKendall trend test under the scaling hypothesis, J. Hydrol., 349, 350-363, doi:10.1016/j.jhydrol.2007.11.009, 2008.

Herrmann, S. M., Anyamba, A., and Tucker, C. J.: Recent trends in vegetation dynamics in the African Sahel and their re- lationship to climate, Global Environ. Chang., 15, 394-404, doi:10.1016/j.gloenvcha.2005.08.004, 2005.

Johnson, V. E.: A Bayesian chi ${ }^{2}$ test for goodness-of-fit, Ann. Stat., 32, 2361-2384, 2004.

Kendall, M. G.: Rank Correlation Methods, Griffin, London, 1975.

Klein Tank, A. M. G., Zwiers, F. W., and Zhang, X.: Guidelines on Analysis of extremes in a changing climate in support of informed decisions for adaptation, Climate Data and Monitoring, WCDMP-No. 72, WMO-TD No. 1500, Geneva Switzerland, 2009.

Kundzewicz, Z. W., Graczyk, D., Maurer, T., Pińskwar, I., Radziejewski, M., Svensson, C., and Szwed, M.: Trend detection in river flow series: 1 . Annual maximum flow/Détection de tendance dans des séries de débit fluvial: 1. Débit maximum annuel, Hydrolog. Sci. J., 50, 797-810, doi:10.1623/hysj.2005.50.5.797, 2005.

Lang, M., Ouarda, T. B. M. J., and Bobée, B.: Towards operational guidelines for over-threshold modeling, J. Hydrol., 225, 103 117, doi:10.1016/S0022-1694(99)00167-5, 1999.

Le Barbé, L., Lebel, T., and Tapsoba, D.: Rainfall variability in West Africa during the years 1950-90, J. Climate, 15, 187-202, doi:10.1175/1520-0442(2002)015<0187:RVIWAD>2.0.CO;2, 2002.

Lebel, T. and Ali, A.: Recent trends in the Central and Western Sahel rainfall regime (1990-2007), J. Hydrol., 375, 52-64, doi:10.1016/j.jhydrol.2008.11.030, 2009.

Lebel, T., Cappelaere, B., Galle, S., Hanan, N., Kergoat, L., Levis, S., Vieux, B., Descroix, L., Gosset, M., Mougin, E., Peugeot, C., and Seguis, L.: AMMA-CATCH studies in the Sahelian region of West-Africa: an overview, J. Hydrol., 375, 3-13, doi:10.1016/j.jhydrol.2009.03.020, 2009.

L'Hôte, Y., Mahé, G., Somé, B., and Triboulet, J. P.: Analysis of a Sahelian annual rainfall index from 1896 to 2000; the drought continues, Hydrolog. Sci. J., 47, 563-572, doi:10.1080/02626660209492960, 2002.

Ly, M., Traore, S. B., Agali, A.; and Sarr, B.: Evolution of some observed climate extremes in the West African Sahel, Weather and Climate Extremes, 1, 19-25, doi:10.1016/j.wace.2013.07.005, 2013.

Mahé, G.: Surface/groundwater interactions in the Bani and Nakambe rivers, tributaries of the Niger and Volta basins, West Africa, Hydrolog. Sci. J., 54, 704-712, doi:10.1623/hysj.54.4.704, 2009.

Mahé, G. and Olivry, J.-C.: Variations des précipitations et des écoulements en Afrique de l'Ouest et centrale de 1951 à 1989, Science et changements planétaires/Sécheresse 6, 109117, 1995.

Mahé, G. and Paturel, J.-E.: 1896-2006 Sahelian annual rainfall variability and runoff increase of Sahelian Rivers, C. R. Geosci., 341, 538-546, doi:10.1016/j.crte.2009.05.002, 2009.

Mahé, G., Diello, P., Paturel, J.-E., Barbier, B., Karambiri, H., Dezetter, A., Dieulin, C., and Rouche, N.: Baisse des pluies et augmentation des écoulements au Sahel: impact climatique et anthropique sur les écoulements du Nakambe au Burkina Faso, Science et changements planétaires/Sécheresse, 21, 330-332, doi:10.1684/sec.2010.0268 2010.

Mahé, G., Lienou, G., Bamba, F., Paturel, J.-E., Adeaga, O., Descroix, L., Mariko, A., Olivry, J.-C., Sangaré, S., Ogilvie, A., and Clanet, J.-C.: Le fleuve Niger et le changement climatique 
au cours des 100 dernières années, in: Hydro-climatology: Variability and Change, Proceedings of symposium J-H02 held during IUGG2011 in Melbourne, Australia, July 2011, IAHS Publ. no. 344, 131-137, 2011.

Mahé, G., Lienou, G., Descroix, L., Bamba, F., Paturel, J. E., Laraque, A., Meddi, M., Habaieb, H., Adeaga, O., Dieulin, C., Chahnez Kotti, F., and Khomsi, K.: The rivers of Africa: witness of climate change and human impact on the environment: How Climate and Human changes impacted river regimes in africa, Hydrol. Process., 27, 2105-2114, doi:10.1002/hyp.9813, 2013.

Mann, H. B.: Nonparametric tests against trend, Econometrica, 13, 245-259, doi:10.2307/1907187, 1945.

New, M., Hewitson, B., Stephenson, D. B., Tsiga, A., Kruger, A., Manhique, A., Gomez, B., Coelho, C. A., Masisi, D. N., and Kululanga, E.: Evidence of trends in daily climate extremes over southern and West Africa, J. Geophys. Res., 111, D14102, doi:10.1029/2005JD006289, 2006.

Nicholson, S.: Climatic and environmental change in Africa during the last two centuries, Clim. Res., 17, 123-144, doi:10.3354/cr017123, 2001.

Nicholson, S.: On the question of the "recovery" of the rains in the West African Sahel, J. Arid Environ., 63, 615-641, doi:10.1016/j.jaridenv.2005.03.004, 2005.

Ozer, P., Erpicum, M., Demarée, G., and Vandiepenbeeck, M.: The Sahelian drought may have ended during the 1990s, Hydrolog. Sci. J., 48, 489-492, doi:10.1623/hysj.48.3.489.45285, 2002.

Panthou, G. : Analyse des extrêmes pluviométriques en Afrique de l'Ouest et de leur évolution au cours des 60 dernières années, PhD thesis, Université de Grenoble, Grenoble, 2013.

Panthou, G., Vischel, T., Lebel, T., Blanchet, J., Quantin, G., and Ali, A.: Extreme rainfall in West Africa: a regional modeling, Water Resour. Res., 48, W08501, doi:10.1029/2012WR012052, 2012.

Panthou, G., Vischel, T., and Lebel, T.: Recent trends in the regime of extreme rainfall in the Central Sahel, Int. J. Climatol., 34, 3998-4006, doi:10.1002/joc.3984, 2014.

Paturel, J. E., Servat, E., Delattre, M. O., and Lubès-Niel, H.: Analyse de séries pluviométriques de longue durée en Afrique de l'Ouest et Centrale non sahélienne dans un contexte de variabilité climatique, Hydrolog. Sci. J., 43, 937-946, 1998.

Paturel, J. E., Ouedraogo, M., Servat, E., Mahe, G., Dezetter, A., and Boyer, J. F.: The concept of rainfall and streamflow normals in West and Central Africa in a context of climatic variability, Hydrolog. Sci. J., 48, 125-137, doi:10.1623/hysj.48.1.125.43479, 2003.

Peterson, T. C., Taylor, M. A., Demeritte, R., Duncombe, D. L., Burton, S., Thompson, F., Porter, A., Mercedes, M., Villegas, E., Semexant F. R., Klein, Tank, A., Martis, A., Warner, R., Joyette, A., Mills, W., Alexander, L., and Gleason, B. : Recent changes in climate extremes in the Caribbean region, J. Geophys. Res., 107, 4601, doi:10.1029/2002JD002251, 2002.
Pettitt, A. N.: A non-parametric approach to the changepoint problem, J. Roy. Stat. Soc. Ser. C-App., 28, 126-135, doi:10.2307/2346729, 1979.

Robson, A. J., Jones, T. K., Reed, D. W., and Bayliss, A. C.: A study of national trend and variation in UK floods, Int. J. Climatol., 18, $165-182,1998$.

Roudier, P., Ducharne, A., and Feyen, L.: Climate change impacts on runoff in West Africa: a review, Hydrol. Earth Syst. Sci., 18, 2789-2801, doi:10.5194/hess-18-2789-2014, 2014.

Sarr, M. A., Zoromé, M., Seidou, O., Bryant, C. R., and Gachon, P.: Recent trends in selected extreme precipitation indices in Senegal - a changepoint approach, J. Hydrol., 505, 326-334, doi:10.1016/j.jhydrol.2013.09.032, 2013.

Schaefer, J. T.: The critical success index as an indicator of warning skill, Weather Forecast., 5, 570-575, doi:10.1175/15200434(1990)005<0570:TCSIAA>2.0.CO;2, 1990.

Sighomnou, D., Tanimoun, B., Alio, A., Ilia, L., Olomoda, I., Coulibaly, B., Koné, S., Sinzou, D., and Dessouassi, R.: Crue exceptionnelle et inondations au cours des mois d'Août et Septembre 2012 dans le Niger moyen et inférieur, Science et changements planétaires, Science et changements planétaires/Sécheresse, 24, 3-13, doi:10.1684/sec.2013.0370, 2013.

Svensson, C., Kundzewicz, W. Z., and Maurer, T.: Trend detection in river flow series: 2. Flood and low-flow index series/Détection de tendance dans des séries de débit fluvial: 2 . Séries d'indices de crue et d'étiage, Hydrolog. Sci. J., 50, 811824, doi:10.1623/hysj.2005.50.5.811, 2005

Tarhule, A.: Damaging rainfall and flooding: the other Sahel hazards, Climatic Change, 72, 355-377, doi:10.1007/s10584-0056792-4, 2005.

Tschakert, P., Sagoe, R., Ofori-Darko, G., and Codjoe, S. N.: Floods in the Sahel: an analysis of anomalies, memory, and anticipatory learning, Climatic Change, 103, 471-502, doi:10.1007/s10584009-9776-y, 2010.

Tucker, C. J., Pinzon, J. E., and Brown, M. E.: Global Inventory Modelling and Mapping Studies, Global Land Cover Facility, University of Maryland, College Park, Maryland, USA, 2004.

Vincent, L. A., Peterson, T. C., Barros, V. R., Marino, M. B., Rusticucci, M., Carrasco, G., Ramirez, E., Alves, L. M., Ambrizzi, T., Berlato, M. A., Grimm, A. M., Marengo, J. A., Molion, L., Moncunill, D. F., Rebello, E., Anunciação, Y. M. T., Quintana, J., Santos, J. L., Baez, J., Coronel, G., Garcia, J., Trebejo, I., Bidegain, M., Haylock, M. R., and Karoly, D.: Observed trends in indices of daily temperature extremes in South America 1960-2000, J. Climate, 18, 5011-5023, doi:10.1175/JCLI3589.1, 2005. 